\title{
Ending Natural Gas Flaring in Nigeria's Oil Fields
}

\author{
Francis Idowu Ibitoye ${ }^{1}$ \\ ${ }^{1}$ Center for Energy Research and Development, Obafemi Awolowo University, Ile-Ife, Nigeria \\ Correspondence: Francis Idowu Ibitoye, Center for Energy Research and Development, Obafemi Awolowo \\ University, Ile-Ife, Nigeria. Tel: 234-803-717-6453. E-mail: fibitoye@cerd.gov.ng
}

Received: January 31, 2014 Accepted: March 4, 2014 Online Published: April 10, 2014

doi:10.5539/jsd.v7n3p13

URL: http://dx.doi.org/10.5539/jsd.v7n3p13

\begin{abstract}
Nigeria has one of the largest ten natural gas reserves in the world and roughly $50 \%$ of the deposits are discovered in association with oil. Over the years most of the associated gas is flared, with the attendant damage to the environment and a huge economic loss. Several efforts have recently been made to curtail gas flaring, including the establishment of a liquefied natural gas plant, a pipeline to transport gas to some neighbouring countries, and legislative measures to regulate the oil and gas industry. Additional projects are being planned and some of these are at various stages of completion. This work presents a three-scenario analysis of current and planned projects aimed at ending gas flaring activities over a study period 30 years $(2010$ - 2040). The first scenario is a business-as-usual case based on existing infrastructures. The second scenario assumes all firm projects are implemented as planned, while the third scenario assumes that, in addition to the firm projects, further projects are implemented. Results of the analysis indicate that existing infrastructure will not be sufficient to end gas flaring in the country. The implementation of firm planned projects in the second scenario will only reduce gas flaring to about $10 \%$ in 2040 . The third scenario of additional projects ensures total elimination of gas flaring. The last two scenarios indicate that 2018 is the year when significant reduction in gas flaring can be achieved in Nigeria. Results also indicate that beyond the firm planned projects in the second scenario, proper timing and sizing of additional projects will be very critical in order to minimise stress on non-associated gas reserves.
\end{abstract}

Keywords: gas flaring, associated gas, non-associated gas, gas flare reduction, petroleum industry bill

\section{Introduction}

Nigeria has one of the ten largest natural gas reserves in the world, with an estimated 5.2 trillion cubic meters (OPEC, 2013), or 2.8\% of total world reserves as at end of 2012. Natural gas supply in Nigeria comes in two streams - gas in isolated wells (or non-associated gas), and gas discovered together with oil, the associated gas. These two sources exist in roughly equal proportions. While non-associated gas can be left underground until needed, associated gas is unavoidably lifted together with crude oil, and must either be harvested or disposed of on site as an unwanted by-product of oil. The usual on-site disposal methods are by venting, if the volume is small enough, or flaring for larger volumes.

Until recently, most of the associated gas produced during oil mining activities was flared because of three main reasons - firstly, domestic demand for natural gas was not large enough to utilise all the associated gas, if recovered; secondly, there was the price tag on recovery of associated gas, which happened to be much higher than that of non-associated gas (ESMAP, 1983) and thirdly, inadequate domestic gas infrastructure to distribute gas to potential consumers. The higher cost of associated gas gathering stems from the fact that the oil fields are generally scattered, and gas collected at one single field may not be large enough for economic purposes. Hence the associated gas collected from these scattered oil fields must first be piped to a common collection point, compressed and transported to a processing unit. Non-associated gas in wells, on the other hand, is mostly found with sufficient pressure, enough to lift the gas a collection point without the need for compression. As it happened then, the reserves of non-associated gas could meet the domestic demand for gas for a long time to come, and there was no real urge to recover the associated gas that was being flared.

Gas flaring has several implications for the environment. Flaring is known to cause heat radiation and thermal conduction into the immediate environment, lead to the production of toxic gases during combustion, produce high noise levels, generate and disperse particulate and other gases such as carbon dioxide $\left(\mathrm{CO}_{2}\right)$ and nitrous 
oxides $\left(\mathrm{NO}_{\mathrm{x}}\right)$ into the atmosphere. These effects are also known to have direct and indirect impacts on human health, soil, vegetation and the atmosphere (Ayoola, 2011; Ajugwo, 2013). In addition, product gases like $\mathrm{CO}_{2}$ and $\mathrm{NO}_{\mathrm{x}}$ also contribute to the global greenhouse effect. A lucid review of the adverse effects of gas flaring and venting, including the socio-economic impacts, is also given by Ite and Ibok (2013). According to Al-Blaies (2011), Nigeria flared a total of 15.2 billion cubic meters of gas in 2010, the second largest in the world (see Table 1). When compared with the quantity of gas flared in 2005 there is about $29 \%$ decrease in gas flaring in Nigeria, mainly due to the implementation of some flare reduction projects. Even then, the quantity of gas flared in Nigeria is still substantive, and as at 2010, the country remains one of the worst offenders when it comes to natural gas flaring, second only to Russia.

There are two main reasons why Nigeria needs to cut down on natural gas flaring - to reduce the damage to the immediate and global environment, and to collect the gas currently being flared for economic activities. Successive Nigerian governments have sort to find a solution to the gas-flaring problem. The Associated Gas Reinjection Act introduced in 1979 prohibited the flaring of associated gas after $1^{\text {st }}$ January 1984, and only allowed specific circumstances on a field-by-field basis after securing a ministerial certificate. Defaulting companies were compelled to pay penalties, about $\$ 1.41$ per thousand cubic meters, which was later increased to $\$ 4.24$ in 1998. Because the fines were so minimal, coupled with the prohibitive cost of gas development projects, many of the international oil companies would rather pay the penalties than embark on projects designed to reduce gas flaring. Hence the Act made little or no difference to the amount of gas flared in the sector.

The gas flare-out date has been shifted several times since the first deadline of 1984, the most recent deadline being December 2012, which also was not enforced. The deadline shifts have been mainly due to lack of adequate infrastructure on ground to achieve the flare-out, and the reluctance of the international oil companies to comply. The latest effort to combat natural gas flaring came in the form of the draft petroleum industry bill. The petroleum industry bill is aimed at establishing legal and regulatory framework for the Nigerian petroleum industry; it is, in addition, to provide guidelines for the operations in the upstream and downstream sectors. In particular, the bill is expected to bring down natural gas flaring in line with international best practices. If it eventually becomes law, the bill will put to an end the flaring of natural gas after a date to be prescribed by the government on any production facility, block or field, onshore or offshore or processing plant, except with expressed permission. Under the bill, gas flares will be metered and monitored; oil companies will be required to report all gas flaring and there are penalties for incorrect reporting and failure to report. Defaulting operators will also be required to pay penalties at extant world market prices for the quantity of gas flared. The bill was first submitted to the National Assembly in 2008 and is still undergoing legislative scrutiny. In anticipation of the petroleum industry bill becoming law, a National Gas Master Plan (NGMP) was also drawn up to serve as a blueprint for rapid development of the gas sector in the country. The Gas Master Plan is premised upon three pillars - improving domestic gas infrastructure, increasing gas export, and making more gas available for the domestic market, especially for power generation, industrial and commercial uses.

This paper focuses on the appropriateness of existing natural gas infrastructure and other planned projects to put an end to gas flaring in Nigeria's oil fields. No assumptions are made on technical details of the gas utilisation plants beyond their capacity and the quantity of feed gas required. Issues related to the chemical composition of natural gas, the adverse effects of natural gas flaring, the social and monetary costs of the gas being flared are already discussed in the literature (Ayoola, 2011; Ajugwo, 2013; Ite \& Ibok, 2013). 
Table 1. Estimated flared volumes from satellite data (2005 and 2010): Top 20 Countries (billion cubic meters, bcm)

\begin{tabular}{lccc}
\hline Country & $2005(\mathrm{bcm})$ & $2010(\mathrm{bcm})$ & \% Change \\
\hline Russia & 58.3 & 35.2 & -39.6 \\
Nigeria & 21.3 & 15.2 & -28.6 \\
Iran & 11.7 & 11.3 & -3.4 \\
Iraq & 7.0 & 9.1 & 30.0 \\
Kazakhstan & 6.2 & 5.4 & -12.9 \\
Algeria & 5.7 & 4.1 & -28.1 \\
USA & 2.8 & 3.8 & 35.7 \\
Saudi Arabia & 3.4 & 3.8 & 11.8 \\
Libya & 4.6 & 3.7 & -19.6 \\
Angola & 4.7 & 2.8 & -40.4 \\
Mexico & 1.9 & 2.5 & 31.6 \\
Venezuela & 2.2 & 2.3 & 4.5 \\
Indonesia & 3.0 & 2.1 & -30.0 \\
China & 3.0 & 2.1 & -30.0 \\
Qatar & 2.3 & 2.1 & -8.7 \\
Oman & 2.6 & 1.9 & -26.9 \\
Canada & 1.3 & 1.9 & 46.2 \\
Egypt & 1.7 & 1.8 & 5.9 \\
Kuwait & 2.5 & 1.5 & -40.0 \\
Uzbekistan & 2.7 & 1.5 & -44.4 \\
Total top 20 & 148.9 & 114.1 & -23.4 \\
Rest of the world & 23.0 & 20.0 & -13.0 \\
Global flaring & 171.9 & 134.1 & -22.0 \\
\hline extracted from Al-Ba. & $(2011)$ & & \\
\hline
\end{tabular}

Source: Flared volumes extracted from Al-Blaies (2011).

\section{Natural Gas Production and Utilisation}

Nigeria has a large deposit of oil and gas, predominantly in the Niger Delta sedimentary basin of southern Nigeria. By the year 2012, according to IEO (2013), proven oil reserves stood at about 37.2 billion barrels, while natural gas is estimated to be of the order of 5.2 trillion cubic meters. In energy terms, Nigeria's gas reserves are more than two times as large as the crude oil reserves. Due to the high gas-to-oil ratio of wells in this basin, gas production has mostly followed oil production trend for a long time. Figure 1 shows natural gas production and utilisation trends between 1970 and 2012. While there appears to be some appreciable increase in natural gas utilisation after 1995, the domestic demand for gas, in relative terms, is still very low, considering the fact the quantity of gas shown Figure 1 to be the amount of gas utilised actually includes the amount of gas re-injected, gas used as fuel in the oil fields by oil companies, and gas used to enhance oil recovery.

The low level of domestic utilisation of natural gas and hence the high flared volumes are attributable to certain factors, amongst which are:

a. The capital intensive nature of gas gathering, transportation and distribution infrastructure, which has curtailed the availability of the resource in potential markets especially those far from the Niger Delta region.

b. The low prices of alternative fuels emanating from the fact that historically these products, mostly petroleum products, are subsidized, resulting in inability to charge gas prices that can make production and distribution to end-users cost-effective. 
c. The low capacity of chemical processing plants and other manufacturing industries which can utilise natural gas as feedstock.

d. In temperate countries, gas is a major energy source for space heating and its use is prominent in both residential and services sectors. Nigeria being a tropical country does not have much need for space heating, and the main requirements for gas in these sectors of the economy will be for cooking, which is likely to be low. As such the infrastructural costs of supplying residential consumers are typically high, making it uneconomical for large population centers not close enough to the distribution network.

As an incentive to make the recovery of associated natural gas more attractive, the Nigerian government in 1990 set in place incentives aimed at wooing foreign investments into the gas sector. These included tax holidays in the form of import duty and value-added tax exemption for equipment and machinery meant for gas projects, lower royalties in comparison with oil, payment of fines for gas flared at fields where authority to flare associated gas was not granted, etc. These developments encouraged major international oil companies to start looking seriously at projects aimed at recovery of the associated gas was being flared.

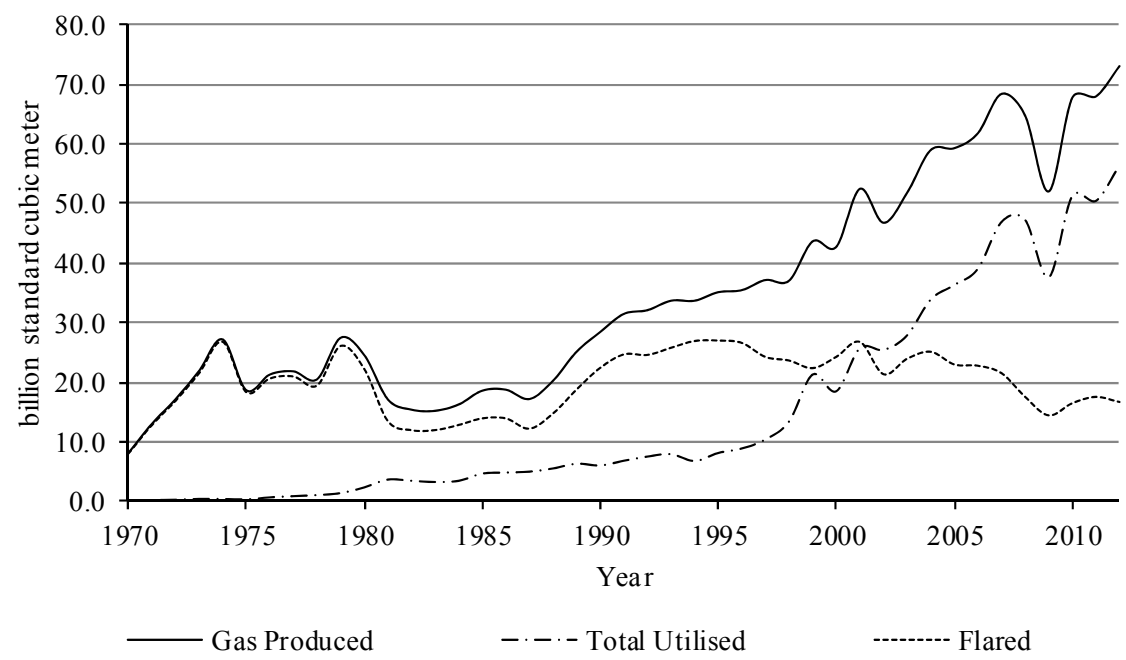

Figure 1. Historical natural gas production and utilisation, 1970-2012

Sources: NNPC $(2002,2011,2012)$.

Aside from wasteful flaring or venting of gas in the oil fields, there are two broad options open for natural gas disposition in Nigeria - these are consumption of the gas within the domestic economy, and exporting the excess gas to the international market.

\subsection{Domestic Gas Consumption}

Currently, the largest single consumer of natural gas in Nigeria is the electricity utility, with an average consumption of 42 million standard cubic meters per day $(\mathrm{mmscm} / \mathrm{d})$ at peak production, or about $70 \%$ of domestic consumption. With an estimated electricity consumption per capita of about $150 \mathrm{kWh}$ per annum in 2010 (NBS, 2012), Nigeria has one the lowest electricity access in Africa. Also, less than $51 \%$ of the populations have access to electricity. Hence one of the most important domestic uses of natural gas will be in gas-to-power projects. An earlier study in this area (Ibitoye \& Adenikinju, 2007) indicated that for Nigeria to move from lowto middle-income country, meet requirements of the millennium development goals and also achieve the status of an industrializing nation, per capita electricity consumption will have to rise to about $5000 \mathrm{kWh}$ by the year 2030. Most of this demand for electricity will have to be met through the use of natural gas power plants.

Another viable route for domestic gas consumption is through the extension of natural gas pipelines to industrial and commercial consumers - cement factories, pharmaceutical and petrochemical companies, food and beverages factories, etc. Demand for gas by industrial and commercial consumers could range between 28 and $42 \mathrm{mmscm} / \mathrm{d}$. Apart from opening up more channels for gas utilization, this will also improve the economy through increased production. 


\subsection{Export-Oriented Gas Projects}

A major option for gas utilization is through direct piping of Nigeria's natural gas across international boundaries, as exemplified by the West African Gas Pipeline project. Other options include processing the gas into secondary products such as liquefied natural gas (LNG), natural gas liquids (NGL), methanol, etc. for export purposes. One major problem here is the need to find ready market for the products, especially in the case of LNG, in view of competition from other international suppliers and volatility of the market.

\section{Existing Natural Gas Infrastructure}

Below are highlights of major natural gas utilisation projects that are already completed and operational:

\subsection{Natural Gas Distribution Pipeline}

The Nigerian Gas Company (NGC), a subsidiary of the Nigerian National Petroleum Corporation (NNPC), was established in 1988 with the specific task of harnessing, developing and marketing natural gas for the domestic market. Presently, its assets include seven gas systems, fourteen compressor stations and over $1000 \mathrm{~km}$ of pipelines. Gas pipeline infrastructure in Nigeria consists of two unconnected networks - the Eastern Network (Alakiri-Obigbo-Ikot Abasi), and the Western Network comprising the $23 \mathrm{mmcm} / \mathrm{d}$ capacity Escravos - Lagos Pipeline System (EPLS) which connects the Escravos gas-rich region in the Niger Delta with the industrial city of Lagos. Initially the 3200 MW Egbin thermal power plant was the only major consumer of the gas supply but the ELPS has become the main gas transmission hub from which several others connections have been made. Third-party companies, notably Gaslink Limited and Shell Nigeria Gas also connect to these two networks to distribute gas to manufacturing companies in Greater Lagos metropolis in western Nigeria, and major industrial areas in the east.

The West African Gas Pipeline (WAGP) is connected to the ELPS and delivers natural gas to some West African countries (notably Ghana, Benin and Togo). The US $\$ 500 \mathrm{~m} 678 \mathrm{~km}$ pipeline was commissioned in 2008 and can deliver up to 5 billion cubic meters of natural gas per annum. Gas delivery through the WAGP has however been epileptic since its completion, due to technical problems and damages to the pipeline. Gas supply resumed mid-2013 after almost one year of repairs.

\subsection{Escravos Gas Plant (EGP)}

This is a joint project between the state owned Nigeria National Petroleum Corporation (NNPC) and Chevron Nigeria Limited (CNL). The origin of this project dates as far back as the early 70s when it became clear that the $\mathrm{CNL} / \mathrm{NNPC}$ fields in the Escravos area contain huge oil and gas reserves. The project is aimed at recovering most of the associated gas in the Okan and Mefa oil fields, and the Escravos off-shore wells. First phase of the project was completed in 1992 and gathers $5 \mathrm{mmscm} / \mathrm{d}$ of gas, producing about 5000 barrels per day of LPG, 10 000 barrels per day of condensate, and $4 \mathrm{mmscm} / \mathrm{d}$ of dry gas. Over the life of the project, gas requirements, assuming continuous operation for twenty years are estimated as 34 billion standard cubic meters. Although the total gas processed by the project amounts to $5 \mathrm{mmscm} / \mathrm{d}$, only a fraction of this - starting at $2 \mathrm{mmscm} / \mathrm{d}$ and declining to $0.3 \mathrm{mmscm} / \mathrm{d}$ can strictly be attributed to associated gas which would have been flared (The World Bank, 1993). The second phase of the EGP expanded capacity of the plant to $8 \mathrm{mmscm} / \mathrm{d}$ and came on stream in 2003 , while a third phase has also been added to yet increase capacity to $11 \mathrm{mmscm} / \mathrm{d}$.

\subsection{The Nigerian Liquefied Natural Gas Plant}

The Nigerian Liquefied Natural Gas (NLNG) is the largest outlet for Nigeria's abundant gas resources. The LNG plant came on-stream in the third quarter of 1999 and currently has six trains, with a total production capacity of 22 metric tonnes of LNG per annum. The seventh train is being planned and expected to boost the capacity to 30 metric tonnes per annum upon completion. The plant presently consumes about $100 \mathrm{mmscm} / \mathrm{d}$. Initial gas feed for this plant was mainly from the non-associated gas stream, and it is expected that the proportion of associated gas will increase and eventually account for the entire supply. Between 1999 and 2012, the plant is reckoned to have converted about 104 billion cubic meters of associated gas which would have otherwise been flared. This is presently the only LNG plant in the country.

\subsection{Oso Gas to Liquids Plant}

The Oso natural gas liquids project is a joint venture between Mobil and the Nigerian National Petroleum Corporation, with Mobil holding 51\% interest. The 50000 barrels per day plant started production in 1998 with and initial 30000 barrels per day, and receives feed gas from the Oso condensate field and other associated gas fields. 


\section{Planned Gas Utilisation Projects}

A number of gas utilization projects are planned in addition to existing ones to ensure reduction of gas flaring in the oil industry to the barest minimum, and also use the captured gas for economic activities. There are firm projects that have reached advanced stages in development, and other proposed projects, mostly those still in the planning stage. The firm projects include the seventh train of NLNG, Brass LNG, and the Escravos gas-to-liquids (EGTL) plant. Other projects being proposed include the Trans-Saharan pipeline and additional LNG plants.

\subsection{Firm Projects}

These are project that have passed through many phases and have reached advanced stages of planning, and are most likely to be funded and completed. These are the NLNG Train 7, Brass LNG, and the Escravos GTL. Start-up dates for these firm projects range from 2015 to 2019.

\subsubsection{NLNG Train 7}

The Nigeria Liquefied Natural Gas plant came on stream in 1999 and presently has six production lines or trains, with a total LNG output of 22 metric tonnes per annum. A seventh train is being proposed and is currently under consideration for final investment decision. Upon completion, this production train will consume about 28 $\mathrm{mmscm} / \mathrm{d}$ of natural gas, boosting annual LNG output of the entire plant to 30 metric tonnes per annum.

\subsubsection{Brass LNG}

The Brass LNG plant is expected to produce 5 metric tonnes of LNG per year and consume $24 \mathrm{mmscm} / \mathrm{d}$ of natural gas. The first train is scheduled to start production in 2018 and a second train is expected to come up one year later. Front-end engineering design has already been completed, and the project, like the NLNG Train 7, is also awaiting final investment decision.

\subsubsection{The Escravos Gas-to-Liquids (EGTL) Plant}

The Escravos gas-to-liquids plant is to be operated by Chevron Nigeria Limited, and jointly owned by Chevron (75\%), Nigerian National Petroleum Company (15\%) and South Africa's SASOL (10\%). The plant will process 9 million cubic meters of natural gas per day into low-sulphur diesel, LPG and naphtha. The plant is expected to receive gas directly from the Escravos gas plant and is now ready for commissioning, following completion of construction works at the plant. The EGTL is a component of the third phase expansion of the Escravos Gas Plant.

\subsection{Other Proposed Projects}

Other proposed projects aimed at curbing natural gas flaring include additional LNG plants and the trans-sahara gas pipeline. Delayed passage of the petroleum industry bill and increasing security concerns in the Niger Delta region have delayed investments in the oil and gas sectors. Furthermore, whether the proposed projects come to fruition or not will depend on the political climate in the country, and also on developments in the global gas market. These additional proposed projects may eventually be abandoned for one reason or another, or face long delays. These projects include the 1.5 metric tonne per annum Progress LNG, the Olokola (OK) LNG and the Trans-sahara gas pipeline.

Progress LNG is a floating LNG plant, the first of its kind in Nigeria, with a production capacity of 1.5 metric tonnes of LNG per annum and anchored offshore. Since this project was first muted in 2004, nothing much has taken place since then.

The Olokola LNG project is a two-train plant jointly owned by the Nigeria National Petroleum Corporation, ChevronTexaco, Shell and BG Group. Plans are that the plant would eventually be equipped with four trains at full capacity. One investor, the BG Group pulled out of the project in 2009, followed later by ChevronTexaco and Shell in 2013, citing lack of progress for the pull-out (Vanguard, 2013). With the withdrawal of all foreign investors, there are strong doubts about the entire project.

The Trans-sahara Gas Pipeline is a $4400 \mathrm{~km}$ pipeline planned to extend from Kano in northern Nigeria to the Beni Saf export terminal in Algeria, with the sole purpose of making Nigerian gas available to the European market. Furthermore, extension of gas pipeline to northern Nigeria will open up fresh enterprises along its route in northern Nigeria, and also in Niger Republic through which the pipeline also runs. Feasibility for this project was concluded in 2006, and the government has already earmarked about US\$400m in the national budget (Nigerian Tribune, 2013) to commence construction of the south-to-north (Calabar-Ajaokuta-Kano) axis of the pipeline. However, the viability of the project is recently being called to question, according to reports (Hydrocarbon Processing, 2013). The project is undergoing review in view of new realities in the domestic and 
international gas markets, especially the discovery of shale gas in many countries around the world. There are also additional security concerns along the entire route of the pipeline and recent political developments in Algeria may further delay investments in the project. Hence, even if the Calabar-Ajaokuta-Kano extension is completed, the pipeline may not extend beyond the Nigerian border for a long time to come.

Nevertheless, because of prevailing uncertainties and the lead time for construction and pre-project activities, none of these projects is expected to start up before 2022.

\section{Methodology}

A natural gas accounting model in the form of a spreadsheet is developed to study the possible disposition of Nigeria's natural gas over a study period of thirty years (2010-2040), with the purposes of reducing natural gas flaring in the oil fields, and monetizing the associated gas that is currently being flared. The model is built on current trends in Nigeria's oil and gas sector, and includes existing and all firm gas utilization projects.

Three likely scenarios are investigated in this work. Scenario A is a business-as-usual or "do-nothing" scenario, whereby it is assumed that no further projects beyond the existing ones are prosecuted. In Scenario B, it is assumed that all firm gas utilization projects are completed and start off as scheduled. Scenario $\mathrm{C}$ assumes that, on the other hand, in addition to the firm projects in Scenario B, the other proposed projects do indeed take off, although delayed because of the uncertainties in the investment climate in the country, terms of access of international oil companies due to non-passage of the petroleum industry bill, and security concerns in the Niger Delta region where most of the oil and gas reserves are located.

\subsection{Model Assumptions}

\subsubsection{Natural Gas Production Trend}

Natural gas production in the near term is not expected to see a dramatic increase because of security problems in the Niger Delta region, coupled with delays in the passage of the petroleum industry bill. This notwithstanding, the reference case projections of IEO (2013) expects that Nigeria's gas export projects will regain their momentum and increase production to 147 billion standard cubic meters in 2040.

\subsubsection{Associated Gas Production Trend}

In this work, associated gas production is tied to oil production trend through the gas-oil-ratio. Results also published in IEO (2013) forecast of oil production indicate that oil production by West African member states of the Organisation for the Petroleum Exporting Countries (OPEC) would rise from 4.4 million barrels per day in 2010 to 5.9 million barrels per day in 2040, or at an average rate of $0.98 \%$ per annum. Since Nigeria belongs to the West African OPEC block, this growth rate is also applied for the projection of oil production in Nigeria. Against this background it is possible to estimate how much of the natural gas predicted in the preceding paragraph will be associated gas, using a five-year average gas-oil-ratio (NNPC, 2012). It should be mentioned that the quantity of associated gas produced would also largely depend on the crude oil production quota allocated to Nigeria by OPEC. Figure 2 shows the projected production trend of associated and non-associated gas, $2010-2040$. Non-associated gas accounts for the difference between gross production and the amount of associated gas produced.

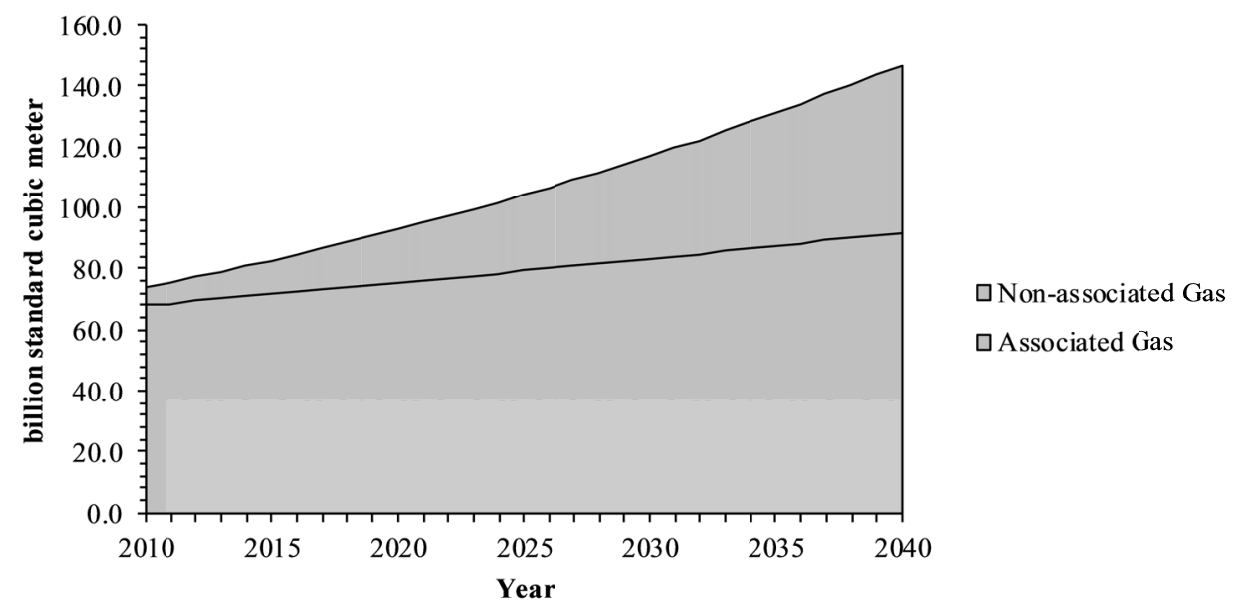

Figure 2. Projected associated and non-associated gas production 


\subsubsection{Gas-to-Power}

Electricity generation from natural gas is accorded a high priority in the National Gas Master Plan. In the Strategic Gas Plan for Nigeria (ESMAP, 2004), electricity generation is projected to grow at the annual rate of $6 \%$, and natural gas demand for this increase in electricity generation is expected to rise from $21 \mathrm{mmscm} / \mathrm{d}$ in 2010 to over $198 \mathrm{mmscm} / \mathrm{d}$ in 2040. With this, per capital electricity would increase to $771 \mathrm{kWh}$ in 2040. Even then, the projected level of consumption in 2040 will still be less than current per capital consumption in countries like Algeria, Egypt, and South Africa, all on the African continent (World Bank, 2013).

\section{Results and Discussion}

Scenario A is a business-as-usual case and assumes that no new projects beyond the existing ones are introduced. Natural gas disposition under Scenario A is shown in Figure 3. In this scenario natural gas flaring reduces to an all-time low of $13 \%$ of gross production between 2020 and 2022, but increases thereafter following the commencement of the retirement of the six LNG trains at NLNG. Under this "do-nothing" scenario, gas flaring increases again progressively after 2023 , peaking at $46 \%$ of production in 2036 , and reduces slowly again as demand for more gas for electricity generation rises.

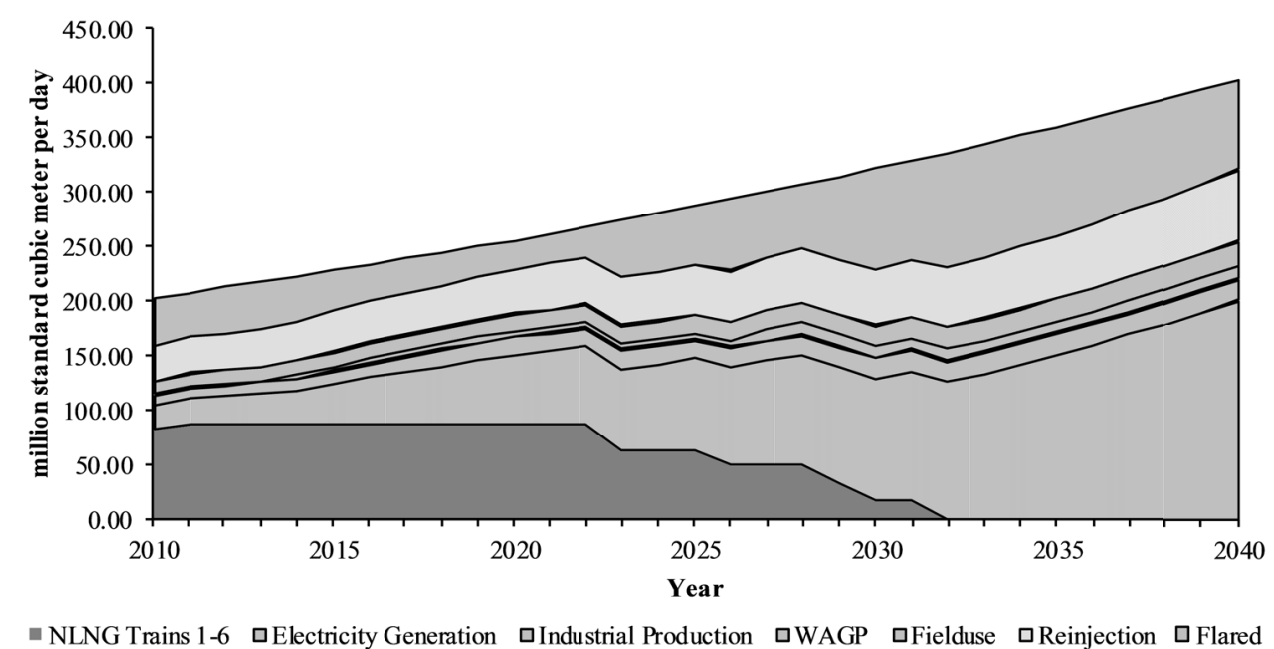

Figure 3. Natural gas disposition - Scenario A: No further gas projects

In scenario B it is assumed that all firm projects are implemented as scheduled. The profile of natural gas disposition is shown in Figure 4. In this figure we observe that natural gas flaring disappears in 2018; this is due to the fact that all gas produced is eventually used up, and the country will have to make up further demand for more gas with the non-associated gas reserves. At the retirement of the last LNG trains of NLNG the country again runs into the problem of associated gas produced but not consumed. By this period, the maximum surplus gas which may likely end up being flared amounts to $16 \%$ of gross production in 2036 . When the amount of gas involved here is compared with historical gas flaring in Nigeria, this may indeed be seen as low-level flaring.

In addition to the completion of all firm projects, Scenario $\mathrm{C}$ assumes that the other proposed projects are also implemented. These other proposed projects include those earlier discussed in section 4.2. The outlook of natural gas disposition is shown in Figure 5. In this figure we observe that gas flaring disappears by 2018 when all associated gas is being produced is eventually used up. The fact that gas flaring could end in 2018 is premised upon the assumption that the practice of natural gas re-injection persists in the oil fields, and at the average rate of $16 \%$ of gross production. If this does not happen, it is likely that some of the gas earmarked for re-injection is indeed flared or vented. It can however be said that under both scenarios B and C, the year 2018 will see the least gas flared in Nigeria's oil industry.

While implementation of additional projects in scenario $\mathrm{C}$ will ensure an end to gas flaring in Nigeria, analysis shows that project timing and sizing is very critical in order to achieve this. For example, it is observed that if the Olokola (OK) LNG project is the only one executed in Scenario C and timed to start production in 2030, this plant alone is sufficient to eliminate gas flaring for the rest of the study period, without placing too much stress on the non-associated gas reserves of the country. 


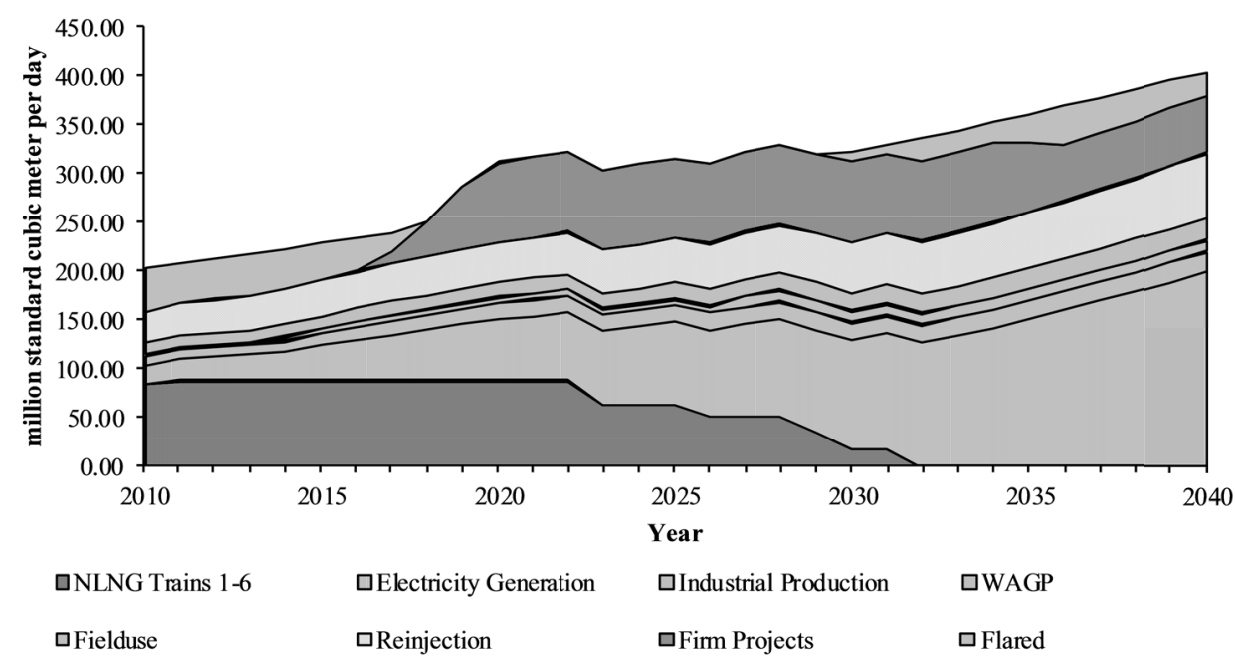

Figure 4. Natural Gas Disposition - Scenario B: All Firm Projects Executed

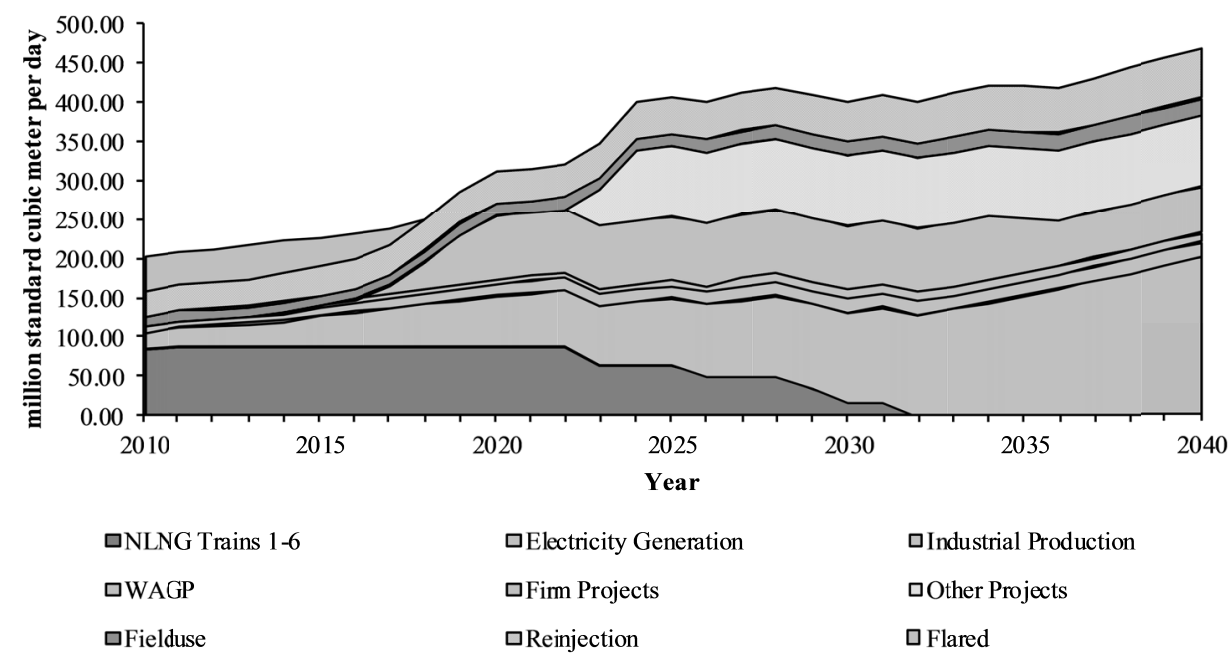

Figure 5. Natural Gas Disposition - Scenario C: Firm and Additional Projects Executed

\section{Conclusions}

Three scenarios have been investigated in Nigeria's effort to reduce gas flaring activities in Nigeria's oil and gas sector. Scenario A shows that current level of infrastructures will not be sufficient to stamp out gas flaring, and additional projects will need to be initiated. Projects introduced in Scenario B will ensure flare reduction to a minimal level, while implementation of further projects in Scenario $\mathrm{C}$ will end natural gas flaring but lead to an increase in the amount of non-associated gas required to meet gas demands. Proper timing and sizing of additional projects is critical for the actualization of gas flare elimination. Properly timing the implementation of a project of the size of the Olokola (OK) LNG plant will ensure total elimination of gas flaring during the study period, without putting too much stress on the non-associated gas reserves of Nigeria. Both scenarios B and C will however see significant reductions in natural gas flaring in 2018.

\section{References}

Ajugwo, A. O. (2013). Negative Effects of Gas Flaring: The Nigerian Experience. Journal of Environment Pollution and Human Health, 1(1), 6-8.

Al-Blaies, W. (2011). Saudi Aramco's Flare Minimisation Program. $7^{\text {th }}$ Gas Arabia Summit, Muscat, Oman, 11-14 December, 2011.

Ayoola, T. J. (2011). Gas flaring and its implication for environmental accounting in Nigeria. Journal of Sustainable Development, 4(5), 244-250. http://dx.doi.org/10.5539/jsd.v4n5p244 
ESMAP. (1983). Nigeria: Issue and Options in the Energy Sector. Report No. 4440-UNI. Washington DC: The World Bank.

ESMAP. (2004). Strategic Gas Plan for Nigeria. Joint UNDP/World Bank Energy Sector Management Assistance Programme. ESM 279 Report 279/04 Washington DC: The World Bank.

Hydrocarbon Processing. (2013). Nigeria to review Trans-saharan gas pipeline. Retrieved December 10, 2013, from http://www.hydrocarbonprocessing.com/Article/3203147/Nigeria-to-review-Trans-Saharan-gaspipeline-plan.html

Ibitoye, F. I., \& Adenikinju, A. (2007). Future demand for electricity in Nigeria. Applied Energy, 84(5), 492-504. http://dx.doi.org/10.1016/j.apenergy.2006.09.011

IEO. (2013). International Energy Outlook. Washington DC: US Energy Information Administration.

Ite, A. E., \& Ibok, U. J. (2013). Gas flaring and venting associated with petroleum exploration and production in the Nigeria's Niger Delta. American Journal of Environmental Protection, 1(4), 70-77. http://dx.doi.org/10.12691/env-1-4-1

NBS. (2012). Annual Abstracts of Statistics. Abuja, Nigeria: National Bureau of Statistics.

Nigerian Tribune. (2013). FG earmarks $\$ 400 m$ for Trans-sahara gas pipeline project. Nigerian Tribune. Retrieved January 15, 2013, from http://www.tribune.com.ng/news2013/index.php/en/component/k2/item/2831-fg-earmarks-\$400m-for-trans -sahara-gas-pipeline-project

NNPC. (2002). Annual Statistical Bulletin 2002. Abuja, Nigeria: Nigerian National Petroleum Corporation

NNPC. (2011). Annual Statistical Bulletin 2011. Abuja, Nigeria: Nigerian National Petroleum Corporation.

NNPC. (2012). Annual Statistical Bulletin 2012. Abuja, Nigeria: Nigerian National Petroleum Corporation.

OPEC. (2013). Annual Statistical Bulletin. Vienna, Austria: Organization of the Petroleum Exporting Countries.

Vanguard. (2013). Chevron, Shell pull out of Olokola LNG project. Retrieved August 30th, 2013, from http://www.vanguardngr.com/2013/08/chevron-shell-pull-out-of-olokola-lng-project/

World Bank. (1993). Escravos Flared Gas Reduction Project. Report No 12178-UNI, Industry and Energy Division, October 20, 1993.

World Bank. (2013). Electric power consumption ( $k$ Wh per capita). Retrieved on December 22nd, 2013, from http://data.worldbank.org/indicator/EG.USE.ELEC.KH.PC

\section{Copyrights}

Copyright for this article is retained by the author(s), with first publication rights granted to the journal.

This is an open-access article distributed under the terms and conditions of the Creative Commons Attribution license (http://creativecommons.org/licenses/by/3.0/). 